\title{
The birth of EU
}

sports law and policy

Despite the absence of a Treaty base, the EU currently operates a sports policy. This policy is the product of activity within the EU's sports policy subsystem, a subsystem formed in response to the infamous Bosman ruling. Prior to that the EU operated a highly polarised and fragmented sports policy characterised by two conflicting policy approaches to sport. First, the EU took a fleeting regulatory interest in sport. The ECJ and the Competition Policy Directorate intervened in sport to correct free movement and competition restrictions and distortions within the Single Market. These interventions were not however informed by the EU's other main policy strand and as a consequence EU sporting actions were not co-ordinated. The second strand of policy involvement in sport involved the EU pursuing a political interest in sport. In particular, sport was identified as a tool through which the EU could strengthen its image in the minds of Europe's citizens. As the two strands of policy involvement in sport did not relate to one another, a policy tension characterised EU sports policy.

Today, the regulatory and political policy strands of EU involvement in sport relate to one another in a more co-ordinated manner. The construction of the separate territories approach to sport has allowed both policy strands to co-exist within the framework of a more co-ordinated sports policy. The practical effect of separate territories is a shift in the nature of EU regulatory involvement in sport. Single Market regulation has become tempered by socio-cultural regulation. In other words, the EU is moving from a market model of regulation towards one in which the EU recognises the social and cultural characteristics of the sports sector within its regulatory approach. By establishing separate territories of sporting autonomy and judicial intervention, the EU has in effect established a distinct legal approach for dealing with sports-related cases. The recent application of law to the sports sector is deeply influenced by the political values embedded within sports policy. Accordingly, current legal interventions in sport balance the EU's regulatory and political policy interests in sport. The development of the separate territories therefore marks the birth of EU sports law. 
EU sports law is therefore a product of the EU's sports policy. The EU lacks the necessary Treaty base to develop a fully fledged common sports policy underpinned with primary and secondary legislative actions. Sports policy is therefore primarily regulatory in nature. It seeks to alter the values which underpin the regulation of sport. In other words, sports policy attempts to balance the classic Single Market regulation of sport with a form of regulation which respects sports social and cultural nature. The clarification of the legal environment allows for the EU's other political policy interests in sport to be pursued without being undermined by Single Market regulatory actions. EU sports policy can then develop through sports integration into a number of socio-cultural policy subsystems such as education, youth and health.

For those seeking to develop a socio-cultural sports policy, the involvement of law is viewed with unease. Sport is an essentially private pursuit which fulfils important social, cultural, educational and physical functions within society. Furthermore, sport and the law are often considered 'separate realms'. In other words, the law operates in a manner totally incompatible with the operation of sport. 'Legal norms are fixed rules which prescribe rights and duties; relationships within the social world of sport are not seen in this way' (Foster 1993: 106). However, sport has never claimed to operate above the law. After all, sport could not operate without law. Rather, it has developed an internal legal structure of its own. On the one hand, this legal system specifies the rules of the game such as the offside law in football. On the other, it also concerns the organisation of the sport. 'Organisational' laws regulate important issues such as access to the competition, the rights of players and the exploitation of broadcasting rights.

Throughout the 1990s sport developed into a significant industry in its own right. The extent of this commercialisation contributed to the juridification' of sport, 'where what are intrinsically social relationships between humans within a social field become imbued with legal values and become understood as constituting a legal relationship - social norms become legal norms' (Gardiner et al. 1998: 66). Juridification therefore refers to the process through which the general laws of the land penetrate the internal laws of sport. The juridification of sport accelerated interest in the idea of sport and the law as an area of legal study. Established general legal principles deriving from, for instance, criminal law, contract law, the law of torts, public law, administrative law, property law, competition law, EU law, company law, fiscal law and human rights law, have been applied to a wide number of sporting contexts including: public order and sport, drugs and sport, safety in sport, disciplinary measures in sport, conduct in sport and wider issues relating to restraint of trade and anti-competitive behaviour in sport.

The extent of the relationship between sport and law has lead some academics to extend their legal analysis beyond the confines of sport and the law 
by identifying a distinct body of sports law (Gardiner et al. 1998, Beloff et al. 1999). As Beloff et al. claim, 'the law is now beginning to treat sporting activity, sporting bodies and the resolution of disputes in sport, differently from other activities or bodies. Discrete doctrines are gradually taking shape in the sporting field' (Beloff et al. 1999: 3). In other sectors the weight of legislation and case law combined with the development of discrete doctrines has led to the creation of other activity-led fields of law. As Gardiner et al. explain:

labour or employment law is a subject area that has only achieved recent recognition. It has its origins in contract law in the employment context, but no one would doubt that with the plethora of legislation during the post-war era regulating the workplace, it has become a subject area in its own right. Passing through various incarnations such as industrial law, it is now a mature legal subject. (Gardiner et al. 1998: 73)

The concept of sports law is not universally accepted. Grayson argues that:

no subject exists which jurisprudentially can be called sports law. As a sound bite headline, shorthand description, it has no juridical foundation; for common law and equity create no concept of law exclusively relating to sport. Each area of law applicable to sport does not differ from how it is found in any other social or jurisprudential category. (Grayson 1994: xxxvii)

Critics of sports law argue that cases involving sport are grounded in the well-established fields of law such as contract and tort. Indeed, 'the traditionally minded, purist lawyer, may indeed distrust any activity-led "vertical" field of law, preferring the surer, traditional ground of rule-led "horizontal" law' (Beloff et al. 1999: 3).

In recent years, the sport and the law versus sports law debate has taken on a new dimension. Commercial pressures and the public's desire to see topclass competition has fuelled the internationalisation of sport. To regulate this cross-border activity, sports governing bodies have established rules governing relations between participants. The international and nongovernmental character of modern sport has not however ushered in for sport a new form of international autonomy insulated from law. The growth of the EU's Single Market has been central to the internationalisation of sports law. The re-regulation of sport has taken place within the context of the Treaty of Rome's fundamental economic freedoms. As the EU is keen to ensure these freedoms are protected, it has applied the Treaty's free movement principles to a growing number of sports-related cases. The ECJ rulings in Walrave, Donà, Heylens and Bosman illustrate the growing relationship between sport and the EU. However, the relationship between sport and the EU has a relevance beyond the narrow confines of regulating economic activity within the Single Market. The EU has social and cultural aspirations and sport has been identified by the EU institutions as one of the tools through 
which these goals can be achieved. Following Bosman, political arguments have penetrated the world of sport and EU law. A new approach for dealing with sports cases is emerging in which the $\mathrm{EU}$ is establishing the boundaries of judicial penetration in sport - in other words the birth of EU sports law. The construction of EU sports law allows the EU's regulatory and political policy objectives for sport to co-exist within the context of an embryonic EU sports policy.

The observation that a distinct body of law known as sports law is emerging in the EU requires both empirical and theoretical justification. One of the weaknesses of the sports law argument is the lack of theoretical underpinning. Although the literature on the emergence of sports law is descriptively strong, it remains unclear at what point the concept of sport and the law loses its relevance and the distinct area of sports law emerges. Furthermore, beyond the assertion that commercialisation has driven juridification, little has emerged on the dynamics driving the birth of sports law. Although sports initial linkage to the EU's legal framework was driven by legal/regulatory norms, the emergence of a distinct field of sports law within a wider sports policy has been politically driven. Within the context of the EU, political science and public policy therefore offer a fruitful venue for analysis. Law should not shy away from the insights offered by other disciplines. One of the most refreshing developments in both law and political science has been the interest shown in 'judicial politics'. As Wincott argues, 'somewhat belatedly the Court of Justice is now being subjected to sustained political analysis and taken into account in the general political science literature on European integration' (Wincott 1996:170).

The birth of EU sports law and policy offers both political science and law the opportunity to further develop this research agenda. Although the politics of sport is a well-developed area of research, the politics of sports law remains largely untouched by political science. As such, political science has been slow in recognising the empirical and theoretical significance of the growth in the EU's sporting activity. It has been law that has colonised this new research terrain. However, law has been equally slow in underpinning its work with theoretical strength, partly because of the practitioner-based focus.

\section{Single market sports regulation: sport and the law 1970-1995}

The EU's first excursion into sporting issues occurred in the 1970s. Two ECJ rulings established important principles governing the relationship between sport and the EU. In Walrave (1974) and Donà (1976) the ECJ established that sport is subject to EU law in so far as it constitutes an economic activity within the meaning of Article 2 of the EEC Treaty, although exemptions from the principle of non-discrimination on the grounds of nationality are permitted but linked with the practise of sport on a non-economic basis. ${ }^{1} \mathrm{~A}$ 
number of years later in Heylens, the ECJ addressed the issue of the recognition of qualifications for sports trainers. ${ }^{2}$ However, it was not until the seismic Bosman ruling of 1995 that the full implications of previous case law became apparent. ${ }^{3}$ In the case, Jean Marc Bosman, a Belgian footballer, successfully challenged UEFA's use of nationality restrictions and the international transfer system.

Walrave, Donà, Heylens and Bosman are examples of cases where the subject matter just so happened to be sport. The well-established principles of the free movement of workers and the freedom to provide services simply became applied to sporting contexts. Although the ECJ did make reference to the specific characteristics of sport, particularly in Bosman, the principles were applied in a manner irrespective of the subject matter.

The European Commission's attitude towards discriminatory/restrictive practises in sport in the aftermath of Walrave and Donà was somewhat contradictory. Despite condemning restrictions on player mobility, the Commission's negotiated settlement approach with the sports world initially resulted in sport and competition law operating in separate realms. The Commission appeared keen to avoid confrontation with the sports world. A number of factors altered this position. The ruling in Bosman acted as an important watershed. Even though in Bosman the ECJ did not address the question of competition law and sport, instead focusing on free movement principles, the Commission used the ruling to justify greater scrutiny of sporting activity. Furthermore, competition law offered individual litigants a more cost-effective venue for redress than the private enforcement route via national courts and the ECJ. The Commission's sports-related competition law caseload swelled considerably following Bosman. Finally, the change in the economic status of sport undoubtedly contributed to juridification.

The juridification and commercialisation of sport are parallel developments in Europe. The commercialisation of European sport is one of the major reasons why a relationship between sport and the EU exists at all. Sport in Europe has traditionally operated in an environment dominated by public service television and in a context where the actions of governmental and non-governmental organisations have co-existed. In organisational and competitive terms, European sport has been organised on a 'pyramid' structure. Organisationally, sports clubs support a structure comprising regional federations, national federations and European federations. Competitively, clubs move up and down a pyramid of competition on the basis of promotion and relegation, i.e. merit-based criteria as opposed to economically based criteria. Since the 1980s, this European 'model' of sport has come under sustained pressure due to the television-led commercialisation of sport. ${ }^{4}$

Until the 1980s the regulation of broadcasting was a matter of purely national jurisdiction. In Britain, for example, competition in broadcasting 
was minimal, often taking the form of a monopoly or a 'comfortable duopoly' (Collins 1994: 146). At the beginning of the 1980s there were very few commercial television broadcasters in Europe, yet by the early 1990s there were 58 (Collins 1994: 146). Technology-driven changes in the field of trans-frontier satellite broadcasting altered the nature of broadcasting in Europe (Collins 1994, Humphreys 1996). With a trend in the 1980s towards the deregulation of national broadcasting markets, new forms of international regulation concerning the new 'Europeanised' broadcasting market took shape. In particular the EU emerged as the key new regulatory actor. The new broadcasting opportunities offered by new technology such as satellite broadcasting greatly benefited the sports sector in Europe. Football in particular was able to sell the broadcasting rights to events to the new wave of commercial operators who had embraced the new technology. As most of these new operators were financed on a subscription basis, revenues were higher than from the public sector broadcasters. This allowed the sports sector in Europe to maximise profits by selling rights to the highest bidder. However, sport's new found wealth merely confirmed the operation of the sports sector in Europe as an economic activity subject to supranational regulation. Nowhere are these above developments better illustrated than in modern European football.

In 1996 Rupert Murdoch, Chairman of News International and leading pioneer of satellite television in Britain remarked, 'we have the long-term rights in most countries to major sporting events and we will be doing in Asia what we intend to do elsewhere in the world, that is, use sports as a battering ram and a lead offering in all our pay television operations'. ${ }^{5}$ For broadcasters, sport is an ideal lead-offering, due to its popularity. The new commercial operators have recognised this. Murdoch added, 'sport absolutely overpowers film and everything else in the entertainment genre and football, of all sports, is number one' (World Soccer 1997).

The introduction of new broadcasting technology greatly changed the English football broadcasting market. In the 1987-1988 season the rights for live league football were sold for $£ 3.1$ million (Spink and Morris 2000: 167). In 1988, British Satellite Broadcasting (BSB) challenged the 'comfortable duopoly' of the BBC and ITV by negotiating a four-year deal with ITV worth $£ 11$ million per season. Having contributed more financially, ITV acquired the exclusive sole rights to league football for the four-year period and by 1991 were broadcasting 18 live matches per season. Evidence therefore suggests that in the UK market up until 1992 with the creation of the Premier League, broadcasters dominated the relationship with the football sector. A number of factors served to redress the balance. First, the football authorities saw the potential benefits of maximising income through the introduction and maturation of a new player, BSkyB. As Parry remarked, 'two is a cartel and three is a market' (Parry 1996: 21). Second, football required wholesale modernisation both on and off the pitch. On the pitch 
top British players were increasingly moving to foreign clubs with no reciprocal flow. This led to fears that the national team would suffer and clubs would not prosper in European competitions. Off the pitch, in the aftermath of the Hillsborough disaster, the Taylor report imposed a large financial burden on clubs by requiring ground modernisation.

In 1992, the newly formed Premier League negotiated a broadcasting contract from a position significantly stronger than in previous years. The deal finally concluded was with the BBC and BSkyB and was worth $£ 214$ million over five years, a significant rise from the previous ITV deal. BSkyB held the exclusive rights to screen live Premier League matches whilst the BBC could screen highlights. Under the terms of the contract, every team was to be broadcast at least once a season. The total number of live games to be broadcast was 60 per season. This compared to 54 in the five years of ITV/BBC coverage. By 1996, the cost of football rights once again rose sharply. The Premier League signed a new $£ 743$ million four-year agreement with BSkyB and the BBC with BSkyB contributing $£ 670$ million. As more broadcasters entered the bidding process so the cost of football rights rose. The launch of digital and cable television services towards the end of the 1990s further increased competition in the rights sector and provided a platform for the development for pay-per-view football. The presence of NTL and ITV Digital in the bidding process for the re-negotiation of the 1996 agreement saw the total value of the rights rise to $£ 1.1$ billion for three years, with BSkyB paying $£ 720$ million to broadcast English Premiership games for a three-year period.

The broadcasting sector and sport have therefore revolutionised each other. 'This marriage between sport and television is one made in heaven' (Griffith-Jones 1997: 289). That was until the collapse of ITV Digital. ITV Digital went into administration and returned its broadcasting licence following the signing in 2000 of the $£ 315$ million contract to broadcast lower league games in England. In July 2002, BSkyB and the Football League signed a $£ 95$ million contract to broadcast Football League games for a fouryear period, an amount considerably less than ITV Digital agreed to pay in 2000 to broadcast the games over three years. This left the Football League with a considerable shortfall in revenue. The Football League sued Carlton Communications and Granada Media arguing that they guaranteed the liabilities of ITV Digital. In Carlton Communications PLC and Granada Media plc v. Football League (2002), the court rejected the Football Leagues claim by finding that the contract between the parties contained no such guarantee. ${ }^{6}$ The resulting recession within the English Football league illustrates the extent to which football relies on broadcasting.

The finances of top-flight football in England and across Europe are not as precarious. The continued mass appeal of top-flight football has resulted in many clubs becoming listed on the stock market. Clubs across Europe are also entering into agreements with media companies. In Italy for instance 
media companies own a share or control AC Milan, Fiorentina, Lazio, Parma and Roma. In Britain, media companies own a stake in Manchester United, Leeds United, Sunderland, Chelsea, Manchester City (all BSkyB), Newcastle United, Aston Villa and Middlesborough (NTL) and Liverpool (Granada). A similar picture is emerging in Europe's other major leagues. The eleventh edition of the 'Deloitte and Touche Annual Review of Football Finances' shows that the income of top-flight European football clubs continues to grow. In 2000/2001 the English Premiership operating profits increased by 51 per cent to $£ 81$ million (134 euros). However, the report found that only the top-flight English and German leagues consistently make an operating profit with broadcasting remaining the single largest source of income for the main leagues in Europe. Despite the difficulties experienced by the English Football League, the report remains positive about the future financial wealth of top-flight football in Europe. New commercial opportunities in the new media remain untapped and the tide appears to have turned regarding cost control in football. In this connection the report argues, 'there is now a remarkable convergence of views across Europe and a real window of opportunity to address the issues around football's cost base'. ${ }^{7}$ In particular salary capping is top of many clubs agendas (see Chapter 5).

\section{The politicisation of Single Market sports regulation 1995-1999}

The commercialisation of sport in Europe was therefore an essential pre-requisite for international juridification. Although Walrave and Donà had established the potential for sport to be linked to the EU's legal framework, the Commission had not completed juridification by applying the EU's competition laws to sport. Following Bosman, the Commission was compelled to respond. The initial post-Bosman relationship between EU competition law and sport was characterised by considerable confusion and great legal uncertainty. Usually acting on a complaint, the Competition Policy Directorate launched a series of high-profile investigations into the operation of sport in Europe. These investigations have included examinations into re-structured transfer systems, competition between sporting federations, rules preventing the multiple ownership of sporting clubs, rules preventing club re-location, the operation of Formula One motor-racing, ticketing arrangements for major sporting events and restrictive practices in the sale and purchase of broadcasting rights and the transmission of sporting events. The extent to which the EU only appeared to acknowledge sports economic potential resulted in the EU attracting considerable criticism from those who thought this approach paid insufficient attention to sports social and cultural significance. The EU's Single Market regulatory approach to sport therefore became politicised.

The relationship between sport and politics is not unique to the EU. The nation state has traditionally pursued a political interest in sport. Work on 
the relationship between sport and the nation state has been subject to numerous studies (Allison 1986, 1993, Cashmore 1996, Houlihan 1997, Greenfield and Osborn 2001). Distilling the main themes from these works, it is possible to identify four main explanations as to why there is a relationship between sport and public policy.

The first broad explanation concerns the use of sport as an instrument of domestic policy in a political system. Governments have used sport as a means through which particular policy objectives can be achieved. Within this category, a number of themes are evident. First, governments have used sport as a means of social integration and control. Governments have used sport as a means of assimilating recent immigrants and of reconciling sectarian, cultural or political differences (Houlihan 1997: 107). Governments have actively promoted sporting activities as a means through which social tensions can be reduced. Not only has sport the potential to tackle the 'problem' of excessive leisure time, it can also promote discipline and self esteem. For example, In Britain the Thatcher government used sport as a means to implement its social policy objectives following urban unrest in the early 1980s. Leisure expenditure was targeted in favour of specific social groups and urban areas. Monnington explains that this policy was a continuation of an approach adopted by the previous Labour government, "but the significant difference now was that justification swung away from provision "as need" in support of welfare principles to provision "as a means"; a means to maintain public order' (Monnington 1992: 144). The regeneration of urban areas through sporting provision allows governments to address more than just social issues. Sport can also be used as a locomotive for economic development and health promotion.

The second explanation concerns the use of sport as an instrument of foreign policy. Sport has traditionally been employed as a means of international protest and boycott. Since the overtly political Berlin Games of 1936, all Olympics have been contested in a political context and boycotts are a common feature. For the first post-war games held in London in 1948, Germany, Italy and Japan were all excluded. The Netherlands, Egypt, Iraq and Spain boycotted the 1956 games in protest at the Anglo-French invasion of Suez. South Africa was suspended from the Olympic movement in 1964 and expelled in 1970, a fate shared by Rhodesia (now Zimbabwe) in 1972 having unilaterally left the Commonwealth. In 1976, 20 African nations boycotted the Montreal Olympics in protest at New Zealand's participation. ${ }^{8}$ The USA boycotted the 1980 Moscow Olympics and most Soviet bloc countries reciprocated by boycotting the Los Angeles Games in 1984. In 1988, Cuba and North Korea boycotted the Seoul Games in protest over South Koreas refusal to share events with North Korea. In addition to protest, sport has also been used as an instrument for promoting a country's international prestige and image. Government's calculate that they will benefit domestically from a positive external image. 
The third explanation concerns the indirect and often unintentional nature of state involvement in sport as a consequence of state policy rather than an instrument of state policy. Although generally disinterested in sport, other than as a means of social control, the activities of Margaret Thatcher's Conservative government in the 1980s had a profound impact on the sports sector. Monnington remarked that 'sport has experienced the consequences of "Thatcherism"' (Monnington 1992: 148). The reform programme of Thatcher, which included compulsory competitive tendering, local management of schools, the opting out of schools from local authority control and more generally local authority restructuring and national curriculum reform, all have had a significant impact on the operation of sport in the UK. Compulsory competitive tendering effectively privatised many publicly owned leisure facilities and forced local authorities to adopt market-based practices for leisure provision. As Monnington reminds us, 'sport is affected in these instances as a consequence of policy, rather than being used as an instrument of policy implementation' (Monnington 1992: 149).

A final theme straddling all of the above explanations concerns an essential pre-requisite for the success of any political system - legitimacy. Sport can be of enormous symbolic benefit to politicians and political systems. Sport can give politics a human face and can reconnect the politician with their constituency. The size and quality of the national stadium reflects the importance of the state itself. Participation, if not success in international competitions such as the Olympics is a defining characteristic of nationhood. Political systems need to be held together by more than the glue of economics, they need to be socially constructed. The EU has acknowledged this problem. Whilst the elitist and bureaucratic path to integration in the $1950 \mathrm{~s}$ and 1960s created the 'new Europe', the lack of popular involvement in the project failed to create 'new Europeans'. The crisis of European integration in the 1970s contributed to the birth of the people's Europe agenda in the mid-1980s. ${ }^{9}$ The failure of the people's Europe agenda to establish itself resulted in widespread public opposition to the Maastricht Treaty. The Danes rejected the Treaty in a referendum and over 49 per cent of French voters rejected it. The British government was forced to call a vote of no confidence to pass the Maastricht Bill through Parliament. In short, the lack of popular support for integration was limiting the ability of governments and the EU more generally to realise their political policy objectives. The sense of remoteness from the EU felt by many of Europe's citizens therefore needed political attention.

The essentially economic approach to sport adopted by the EU sat uncomfortably with the general theme of a people's Europe. Through Bosman the EU became associated with emancipating very rich footballers, thus making them even richer. The EU was seen as a venue through which the full commercial potential of sport could be exploited at the expense of the real values of the game. As such, the EU was not reconnecting itself with its citizens, it 
was taking the people's game further away from them. A body of opinion emerged within the EU seeking to give the socio-cultural and integrationist qualities of sport a higher priority and for sport to be afforded a higher level of protection from EU law. The European Parliament emerged as an important venue through which such ideas were discussed. Both the 1994 'Larive report' on the European Community and Sport and the 1997 'Pack report' on the 'Role of the European Union in the Field of Sport' demonstrated a desire to balance the economic regulation of sport with the promotion of sports socio-cultural and integrationist qualities. ${ }^{10}$ Furthermore, the Parliament has been successful in inserting an amendment into the second Television Without Frontiers Directive (TWF) in 1997, guaranteeing public viewing access to major sporting events on television. ${ }^{11}$

Sport also received the attention of the member states. Following Bosman, calls intensified for sport to be granted a legal base within the European Treaty. The proponents of such a move hoped that a legally based Article for sport would limit what was perceived as the insensitive application of EU law to sport whilst granting the EU a legal base to develop a sociocultural common sports policy. Despite the strength of support, the Heads of State and Government meeting in Amsterdam in June 1997 decided only to attach a non-binding Declaration on Sport to the Amsterdam Treaty which called on the institutions of the EU to recognise sports social significance. ${ }^{12}$ Although the Declaration disappointed those who wished to see a legal competence for sport established within the Treaty, the Declaration is significant in that by implicitly criticising Bosman it has served to politicise sport and the law in the EU. Member states have followed up the Declaration by releasing important political guidelines on sport and the $\mathrm{EU}$ in the form of Presidency Conclusions. In this connection, the member states confirmed their determination to see the regulation of sport balanced by a sociocultural agenda at Vienna (December 1998), Paderborn (June 1999), Helsinki (December 1999) and during the Portuguese (first half of 2000) and French (second half of 2000) Presidencies of the Council of the European Union.

The Commission's institutional response to the Amsterdam Declaration came throughout 1998 and 1999. The Education and Culture Directorate (then known as DG X) published series of papers on sport. 'The Development and Prospects for Community Action in the Field of Sport' and 'The European Model of Sport' stressed the multi-dimensional nature of sport and established dialogue with the sports world. ${ }^{13}$ Attached to the "The European Model of Sport' document was a questionnaire designed to canvass opinion on the future direction of the EU's involvement in sport. The findings of this exercise were used by the Commission to prepare the first EU conference on sport held in Greece in May 1999. The conclusions of the Conference were then used by the Commission to prepare a report, at the European Council's request, on an approach to safeguarding current sports structures and maintaining the social function of sport within the EU framework. The report 
was submitted to the December 1999 Helsinki European Council. At the heart of the 'new approach' embodied in the Helsinki report is a framework for applying EU law to sport. The report claims that 'this new approach involves preserving the traditional values of sport, while at the same time assimilating a changing economic and legal environment'. ${ }^{14}$ The Helsinki report therefore represents the EU's first attempt to co-ordinate the Single Market and socio-cultural policy strands of its involvement in sport. In essence, the report establishes an embryonic EU sports policy. However, it is a policy which is curiously unattached to the Treaty. In the absence of specific primary and secondary sports legislation, the glue binding the policy strands together is sports law.

\section{Socio-cultural sports regulation: the birth of EU sports law 1999}

The assertion by Beloff $e t$ al. that a discrete area of sports law exists is supported by their observation that the English courts have established the parameters of judicial intervention in sport.

The cornerstone of what could be called the founding principles of sports law is the definition of respective territories of the courts and the bodies which govern sport. The courts in England and elsewhere have firmly established a region of autonomy for decision making bodies in sport, a region which unless the reasons for doing so are compelling - the courts decline to intervene. Equally firmly they have charted the outer limits of that region and insisted that those limits be observed by the decision makers in sport, on pain of judicial intervention. (Beloff et al. 1999: 4)

Beloff et al. note that the 'courts in England and elsewhere' have established these territories. Although it is unclear exactly what 'elsewhere' refers to, it is argued in this text that similar territories are beginning to appear in the EU. Of course, placing too much distance between the English legal system and that of the EU would be misleading. EU law is supreme and can carry direct effect and direct applicability. In other words, EU law takes precedent over national law where the two come into conflict (supremacy) and EU law can take legal effect into the national legal systems without the need for national implementation measures (direct applicability) whilst giving rise to rights or obligations on which individuals may rely before their national courts (direct effect). Furthermore, Article 234 of the Treaty creates an organic link between the two systems by providing for a preliminary reference procedure for national courts to seek clarification from the ECJ on matters concerning the interpretation and validity of EU law. Clearly therefore this distinction between national patterns of sports law and EU sports law is somewhat artificial. Nevertheless, the EU is not a state in the classic mould of nation states. As an organisation it blurs the boundaries between the executive, legislative and judiciary. The Commission for instance possesses quasi-judicial powers in relation to the operation of competition law. 
The ECJ works under the threat of sanction from the European Council. Furthermore, the EU is a curious hybrid of political, bureaucratic and legal styles and cultures. It is, in short, a system without direct comparison in Europe. As a source of English sports law, EU sports law therefore merits separate attention.

EU sports law was born out of the post-Bosman political discussions on the future of sport in the EU. It is an essential component of modern EU sports policy. Accordingly, it is a very recent development. The argument that a distinct area of EU sports law has emerged therefore risks the challenge that this is a premature claim. Soft law is included within the definition of EU sports law. Soft law refers to rules of conduct which in principle have no legally binding force but which nevertheless may have a significant effect on policy and legal developments. Soft law refers to non-binding measures adopted by the EU institutions such as Treaty Declarations, Presidency Conclusions, political guidelines and Commission orientation papers, comfort letters and notices.

The use of soft law stems from the peculiarities of the EU's system of law and governance. The EU is obviously a multi-national organisation. The size, complexity and diversity of the EU results in protracted decision making at the best of times. In the absence of unanimity, member states often favour the use of soft law when they are unable to agree upon binding measures but nevertheless wish to place political pressure on the EU institutions for a change in policy direction. As such, soft law can be employed by the member states as an implied threat of taking further harder measures unless EU institutions change their approach. Soft law has therefore offered important guidance as to the interpretation and scope of the application of EU law. The Amsterdam Declaration is increasingly a frequently sourced reference in Commission competition law cases and ECJ cases. The Commission (in this context the Competition Policy Directorate) also favours the use of soft law. Politically, the Commission must be sensitive not only to the interests of the member states, but also to the requirements of business operating in the Single Market. Soft law is therefore often used as the politically pragmatic option. The voluntary notification system used in competition law also lends itself to the use of soft law. Furthermore those seeking clearance often favour informal negotiated settlements. The Commission is also hampered by resource limitations which results in the use of administrative rather than judicial measures to resolve cases. In addition, it is not uncommon for soft law to be used as quasi-legal justification by EU institutions for the development of policy initiatives. Again, the Amsterdam Declaration on Sport has informed much of the EU's recent sports-related activity. Soft law has therefore characterised much of the development of EU sports law. The lack of a formal Treaty base to take 'harder' measures in sport clearly also necessitates the use of soft law.

The Commission's first formal post-Amsterdam review of the application 
of competition rules to sport came in a policy paper in February $1999 .{ }^{15}$ In the paper the Competition Policy Directorate made a distinction between purely sporting situations which are not covered by the scope of competition law and wholly commercial situations to which Treaty provisions will apply. Even though the distinction between sporting rules and commercial rules is problematic, the Commission recognised that even concerning commercial rules the particular characteristics of sport must be taken into account. The paper represents the first attempt to establish the respective territories of sporting autonomy and judicial intervention. Through Commission case law, attempts have been made to further define these territories. The Commission's recognition of the specificity of sport has been demonstrated in cases concerning the collective sale of sports broadcasting rights, collective purchasing agreements, restrictions on the cross-border transmission of sport, ticketing arrangements, issues concerning the maintenance of the single structure model of sport, multiple club ownership, club relocation, the operation of Formula One motor racing, the granting of state aid to sport and the operation of the international transfer system for players. ${ }^{16}$ Whilst the Commission has closed some of the above cases through formal decisions, in many instances it has relied on informal negotiated settlements and other soft law measures.

The absence of black letter law in the field of sport is on the one hand understandable. 'Sporting bodies continue to argue that, while competition law is generally an adequate mechanism for regulating normal markets, it can often be too crude to be applied to markets touched upon by sport, because sport operates under different market conditions to other sectors' (Kinsella and Daly 2001: 7). The use of informal soft law measures can therefore be defended on the grounds of flexibility and sensitivity to the concerns of sport. As such, the use of soft law represents a distinct quasi-legal approach in its own right. Of course, soft law poses a number of problems. Although sport favours the negotiated settlement approach, the lack of clear precedents leaves the regulatory environment as confusing as ever. The adoption of harder measures would arguably benefit sport through the establishment of legally binding respective territories of sports autonomy and legal intervention. The Commission's proposal to increasingly share the burden of applying competition law (including the exemption procedure) with national regulatory bodies and courts rests on the assumption that sufficient case law has been acquired to facilitate this decentralisation. ${ }^{17}$ As Kinsella and Daly observe, the lack of harder measures adopted by the Commission in the field of sport means that this case law experience has not yet been acquired (Kinsella and Daly 2001: 13). Given the lack of hard sports law and the general vagueness of Article 81, the future of the competition law component of the separate territories is uncertain.

The recent activities of the ECJ further illustrate the extent to which political arguments have permeated traditionally legal domains. The ECJ's 
sports-related rulings in Deliège and Lehtonen further develop the concept of respective territories. ${ }^{18}$ Although in Walrave, Donà and Bosman the ECJ recognised the special characteristics of sport thus acknowledging the distinction between economic and social activities, the rulings essentially attempted to extend the scope the of the free movement principle. By contrast, Deliege and Lehtonen established sports specific limitations (albeit limited ones) on the scope of the principle of free movement. It is worth noting that in Deliege and Lehtonen the ECJ took the somewhat unusual step of referring to the Amsterdam Treaty's Declaration on Sport.

The impact of this soft law Declaration has therefore been significant. The member states have subsequently declined the invitation made by the Parliament and representatives of the sports world to harden the Declaration into a Treaty Article or protocol for sport. Meeting during the Nice Summit in December 2000, the member states did however re-visit the Declaration in light of the on-going discussion between the Commission and FIFA/ UEFA on the re-modelling of the international transfer system. The Nice Declaration on Sport (released as a Presidency Conclusion) represents the member states contribution to the debate on the birth of EU sports law as part of a wider EU sports policy. Whilst the Amsterdam Declaration ran to just 58 words, the Nice Declaration was over 1,000 words. The significant passage read,

even though not having any direct powers in this area, the Community must, in its action under the various Treaty provisions, take account of the social, educational and cultural functions inherent in sport and making it special, in order that the code of ethics and the solidarity essential to the preservation of its social role may be respected and nurtured. ${ }^{19}$

Without formally granting sport a Treaty base, the above passage in effect launches an informal member state commitment to launch an EU sports policy in which the construction of EU sports law is the defining characteristic.

\section{Conclusions}

The birth of EU sports law is essential to the viability of a EU sports policy which is not legally rooted to the Treaty. EU sports law allows the EU's regulatory interest in sport to co-exist with its other political sporting objectives. The birth of EU sports law and policy is further promoted by the arena in which the debate on sport is taking place in the EU. A sports policy subsystem has emerged in the EU composed of coalitions of actors attempting to steer sports policy in a direction consistent with their belief system. The Single Market advocacy coalition pursues a regulatory policy interest in sport. It stresses the economic significance of sport. Sport and law therefore collide whenever sport is practiced as an economic activity. The activities of 
the Single Market coalition established the Single Market model of sports regulation in the EU. The socio-cultural advocacy coalition has, by contrast, pursued a more socio-cultural and educational policy interest in sport. Sport should therefore be treated differently to other economic sectors before the law. Furthermore, sport should be much more closely integrated into the EU's system in order to enhance the prospects of achieving a people's Europe. The activities of the socio-cultural coalition have shifted the nature of the EU's regulatory involvement in sport towards a socio-cultural model. The birth of EU sports law has taken place within the context of this socio-legal and essentially political discussion between advocacy coalitions over the direction of sports policy. The development of sports law is an approach favoured by both coalitions as it allows them to protect their fundamental belief systems.

Chapter 2 explores the theoretical basis for this claim. As politics is considered to be the mid-wife in the birth of EU sports law, the approach favoured is drawn from political science/public policy. Policy subsystems and advocacy coalitions are considered key arenas in which policy change takes place. Yet, in order to appreciate the dynamics of policy change it is important to locate the work of advocacy coalitions within an institutional context. The institutional resources at a coalition's disposal have a consequential impact on its ability to shape law and policy in the EU.

Chapter 3 analyses the operation of the sports policy subsystem by examining the composition of the two central advocacy coalitions and by specifying the institutional powers they have at their disposal. Unable to influence policy in one venue, a strongly resourced coalition will be able to go 'venue shopping' in order to try its luck in others. The control of venues by advocacy coalitions is problematic in the EU. The contemporary EU is a multilevel organisation. Treaty change has altered the balance of power between the EU institutions. As such, the EU is now considered a paradise for the agenda setter. Even subsystems traditionally dominated by legal and technocratic norms are no longer insulated from wider political and public policy concerns.

Chapter 4 begins the review of the legal context of sports relationship with the EU. The ECJ rulings in Walrave, Donà, Heylens, Bosman, Deliège and Lehtonen receive particular attention. The chapter traces the development of ECJ jurisprudence from the initial application of general EU legal principles such as the right to free movement to the emergence of a more distinct area of EU sports law.

Chapter 5 continues the case law analysis by examining the relationship between sport and EU competition law. The method of disposing of its sports-related caseload tells us much about the Commission's approach. Faced with administrative and political pressures, the Commission has sought to establish an approach for dealing with sport which differs from the general approach to market regulation. 
Chapter 6 explores the political context of sports relationship with the EU. A combination of sport's popularity among Europe's public and the EU's wider political/public policy objectives for sport has served to politicise the sports policy subsystem. Previously dominated by legal norms, the subsystem has become penetrated by political arguments over the direction of sports policy. The peculiar multi-level nature of the EU combined with the public law nature of the EU's legal system allows for the expression of wider public-interest justifications for prima facie restrictive sports rules. In other words, the EU and its legal system exists for reasons other than simply to resolve disputes between sports economic stakeholders. The 'state', defined broadly to include the EU institutions, has interests in this field as well. However, just as the EU's institutional structure can act to promote agenda expansion, so it can frustrate and constrain actors. The birth of sports law has not been legislatively driven as the EU has no Treaty base to develop sports legislation. The non-legislative politicisation of law has therefore been at the heart of the socio-cultural coalition's approach. The use of soft law as a counterweight to the unavailability of legislation has therefore been a preferred tactic.

Chapter 7 examines the future of EU sports law and policy. The future is as open ended as it has ever been. The claims of predictive breakthroughs traditionally perpetuated in political science is rejected. Nevertheless, by establishing the analytical methodology employed in this text it is possible to make some conditional assumptions on the future of sports law and policy in the EU.

\section{Notes}

1 Case 36/74, Walrave and Koch v. Association Union Cycliste Internationale [1974] ECR 1405. Case 13/76, Donà v. Mantero [1976] ECR 1333.

2 Case 222/86, UNECTEF v. Heylens [1987] ECR 4097.

3 Case C-415/93, Union Royale Belge Sociétés de Football Association and others v. Bosman [1995] ECR I-4291.

4 See 'The European Model of Sport', Consultation Document of DG X, 1998.

5 Address by Rupert Murdoch to News Corporation AGM in Adelaide, 15/10/96.

6 Carlton Communications PLC and Granada Media plc v. Football League [2002] EWHC 1650, QBD Commercial Court, Langley J, 1 August.

7 For a summary of the report see Sports Law Bulletin, 5 (4) July/August 2002.

8 Despite world opinion, New Zealand maintained sporting links with South Africa.

9 COM (84) 446 Final, 'A People's Europe', Reports from the ad hoc Committee.

10 A3-0326/94/ Part A (27/4/94) Part B (29/4/94), 'Report on the European Community and Sport', Rapporteur: Mrs J. Larive. A4-0197/97, 'Report on the Role of the European Union in the Field of Sport' (28/5/97), Rapporteur: Mrs D. Pack.

11 Article 3a Directive 97/36/EC. 
12 Declaration 29, Treaty of Amsterdam amending the Treaty on European Union, the Treaties establishing the European Communities and certain related Acts, 1997.

13 Developments and Prospects for Community Activity in the Field of Sport', Commission Staff Working Paper, Directorate General X, 29/09/98 and 'The European Model of Sport', Consultation Document of DG X. 1998.

14 Com (1999) 644, 'Report from the Commission to the European Council with a View to Safeguarding Sports Structures and Maintaining the Social Significance of Sport within the Community Framework', The Helsinki report on sport', 1/12/99.

15 DN: IP/99/133, 'Commission Debates Application of Its Competition Rules to Sport', 24/02/99.

16 For a review of these cases see Chapter 5.

17 COM (2000) 582 Final, 'Proposal for a Council Regulation on the Implementation of the Rules on Competition Laid Down in Articles 81 and 82 of the Treaty and Amending Regulations' (EEC) No. 1017/68, (EEC) No. 2988/74, (EEC) No. 4056/86 and (EEC) No. 3975/87. ('Regulation Implementing Articles 81 and 82 of the Treaty'), 27/09/00.

18 Joined cases C-51/96 and C-191/97, Deliège v. Asbl Ligue Francophone de Judo and others [2000] ECR I-2549. Case C-176/96, Jyri Lehtonen and Castors Canada Dry Namur-Braine v. Fédération Royale des Sociétés de Basketball and Ligue Belge-Belgische Liga [2000] ECR I-2681.

19 Declaration on the Specific Characteristics of Sport and its Social Function in Europe, of Which Account Should be Taken in Implementing Common Policies, Presidency Conclusions, Nice European Council Meeting, 7, 8, 9 December 2000 . 